\title{
Pendidikan Islam Perspektif Pesantren: Diferensiasi, Aplikasi dan Motivasi
}

\author{
Jasminto \\ Universitas Hasyim Asy'ari \\ jasminto2010@gmail.com
}

\begin{abstract}
This article discusses several definitions of Islamic education and gives guidelines to clarify the use of the definition. The article describes that the definition depicts the typology of Islamic education and institutions related to it. This will explain the different concepts that depend on the context of Islamic education, especially with regard to pondok pesantren. Later, the article elucidates the theoretical conception of Islamic education based on the Qur'an and hadith. This article argues that the primary motivation of the holistic approach of 'Islamic education' of pesantren can be used as the representative of Islamic education in the world that teaches religious moderation.
\end{abstract}

Keywords: Islamic education; pondok pesantren; holistic, religious moderation

\section{Pendahuluan}

Perubahan mendasar terkait budaya manusia yang disebabkan efek politik, ekonomi, dan sosial semakin cepat dengan adanya pandemi covid-19 di seluruh penjuru dunia, ${ }^{1}$ demikian ini akan bermuara pada ancaman krisis multidimensi. ${ }^{2}$

\footnotetext{
${ }^{1}$ Enrico Marpaung et al., Pandemi COVID-19: Dampak Sosial-Ekonomi, Tantangan, Dan Potensi Solusi (Sudut Pandang Sosiologis) (Makalah Dipresentasikan sebagai Tugas Mata Kuliah Demografi Sosial, Jakarta, Mei 2020).
} 
Perubahan yang cepat tersebut menuntut manusia mampu beradaptasi dan memahami posisinya di dunia secara global. Proses adaptasi tersebut menjadi penting dikarenakan ketika daerah dan budaya bersentuhan satu sama lain, seringkali sulit bagi orang-orang untuk mengenali gagasan, nilai, dan institusi paralel dalam komunitas masyarakat lainnya. ${ }^{3}$ Adaptasi yang cepat berdasarkan pemahaman akan meredam dampak negatif yang disebabkan pandemi covid-19.

Perbedaan jarak antar masyarakat secara global membutuhkan jembatan penyambung agar komunikasi dan interaksi dapat berlangsung secara terbuka. Era ketersambungan masyarakat itulah yang kini terwujud dalam bentuk teknologi informasi dan komunikasi. ${ }^{4}$ Kemajuan teknologi informasi dan komunikasi mengantarkan interaksi secara global yang memiliki dampak serius dalam keterbukaan akses di setiap bidang. Meskipun trend kemajuan teknologi informasi dan komunikasi banyak memiliki dampak positif namun identitas suatu masyarakat menjadi taruhan jika tidak memiliki filter yang kuat. "Islam" sebagai salah satu agama yang berfungsi menjadi filter atas dampak negatif di era keterbukaan informasi, silang budaya dan ideologi berperan sebagai penanda di lingkungan masyarakat global. ${ }^{5}$

Islam yang kemudian menjadi penanda bagi para pemeluknya terhadap apa yang mereka lakukan merupakan transformasi pemahaman terhadap masyarakat muslim itu sendiri. Dengan berjalannya waktu perilaku muslim tersebut mendapat label "islami" yakni perilaku muslim yang didasari praktik atas pemahaman keagamaannya. ${ }^{6}$ Istilah islami dipakai umat islam untuk menunjukkan sisi positif atas sebuah perilaku masyarakat yang kemudian diformalkan pada kelompok, institusi dan lembaga. Dengan berjalannya waktu istilah islami kemudian dipahami sebagai perilaku umat Islam secara umum sehingga istilah yang awalnya diperuntukkan untuk sisi positif bisa menjadi

\footnotetext{
${ }^{2}$ Dedy Afrianto, "Pandemi: Dari Kesehatan, Ekonomi, Hingga Politik," Kompas, 22 Juli, 2020.

3 Young Y Kim, Intercultural Transformation." In Becoming Intercultural: An Integrative Theory of Communication and Cross-Cultural Adaptation (Thousand Oaks, California: SAGE Publications, Inc., 2001).

${ }^{4}$ Nursinita Killian, "Peran Teknologi Informasi Dalam Komunikasi Antar Budaya Dan Agama," Jurnal Dakwah Tabligh 15, no. 2 (2014): 159-76.

${ }^{5}$ Arief Rifkiawan Hamzah Heri Cahyono, "Agama Dan Tantangan Budaya Modern Perspektif Islam,” Fikri : Jurnal Kajian Agama, Sosial Dan Budaya 1, no 2 (2016): 421-48.

${ }^{6}$ Zunly Nadia Nadia, "Perilaku Keagamaan Komunitas Muslim (Pemahaman Hadis Dalam NU Dan Salafi Wahabi Di Indonesia)," Jurnal Living Hadis 2, no 2 (2017): 141-77.
} 
kebalikannya karena perilaku umat islam secara umum. ${ }^{7}$ Awal istilah terorisme yang dilekatkan dengan istilah islami ini sering didapati pada pemberitaanpemberitaan internasional pasca peristiwa 11 September $2001^{8}$ merupakan wujud kerancuan atas penggunaan kata islami. Definisi buruk tersebut disebabkan kegagalan dalam membedakan Islam sebagai doktrin dan Islam sebagai perilaku sebagian penganutnya di lingkup budaya, sosial dan politik..$^{9}$ Sehingga istilah yang digunakan untuk menandakan Islam dan Muslim kurang sesuai ketika digunakan oleh umat Islam dan orang lain dalam wacana publik.

Untuk mencegah kesalahpahaman total yang dapat menyebabkan kesalahan karakterisasi dan bahkan islamophobia sebagai bentuk kebencian kepada muslim, istilah-istilah yang menjadi penyebab kesalahpahaman perlu dieksplorasi dan diklarifikasi. ${ }^{10}$ Setelah serangan pada 11 September 2001, wacana publik di dunia, khususnya di Eropa tentang Islam didominasi sifat negatif berupa teroris dan ekstrimis. Terlebih, berbagai analisa media menuduh pendidikan islam sebagai salah satu penyebab apa yang mereka sebut radikalisme dan teroris dalam Islam. ${ }^{11}$ Tentu, tuduhan tersebut harus dijawab dengan mengeksplorasi konsep dan praktik pendidikan Islam sebagai bentuk klarifikasi yang efektif terhadap tuduhan dan justifikasi mereka yang berada di luar sistem. Upaya klarifikasi melalui eksplorasi pendidikan islam secara universal bisa dimulai dari pesantren sebagai lembaga pendidikan islam awal di Indonesia yang sampai kini masih eksis. ${ }^{12}$ Pemilihan pesantren sebagai contoh pendidikan Islam yang mengcounter tuduhan radikalisme dan terorisme dikarenakan pesantren di indonesia mengajarkan islam secara moderasi dan wasathiyah sebagai upaya deradikalisasi

7 Samhi Muawan Djamal, "Pelaksanaan Nilai-Nilai Ajaran Islam Dalam Kehidupan Masyarakat Di Desa Garuntungan Kecamatan Kindang Kabupaten Bulukumba,” Jurnal Adabiyah 17, no. 2 (2017): 161-79.

${ }^{8}$ Hanan Qisthina Sindi, Reni Windiani, dan Sheiffi Puspapertiwi, "Analisis Perilaku Kejahatan Terorisme Osama Bin Laden,” Journal of International Relations 2, no. 4 (2016): 93-98.

9 Sokhi Huda, "Islam Dan Politik: Doktrin, Realitas, Dan Akses Sosiologisnya" (Makalah Dipresentasikan pada Seminar Kelas Mata Kuliah Sosiologi Agama, Program Pascasarjana Institut Agama Islam Negeri Sunan Ampel Surabaya, Juni 1999)

${ }^{10}$ Moordiningsih, "Islamophobia dan Strategi Mengatasinya," Buletin Psikologi 12, no. 4 (Desember 2004): 73-84.

11 Abdul Kholik, "Pendidikan Islam Dan Fenomena Radikalisme Agama," Jurnal Kependidikan 5, no. (2017): 10-19.

12 Ayub Mursalin dan Ibnu Katsir, "Pola Pendidikan Keagamaan Pesantren Dan Radikalisme: Studi Kasus Pesantren-Pesantren Di Provinsi Jambi,” Kontekstualita: Jurnal Penelitian Sosial Keagamaan 25, no. 2 (2010). 
pemahaman keagamaan yang menyebabkan ekstrimisme. ${ }^{13}$ Pengeksplorasian pesantren secara diferensial, aplikasi dan motivasi dibutuhkan untuk menjawab berbagai tuduhan pendidikan islam sebagai cikal bakal teroris dan radikalis Islam.

Pesantren sebagai bentuk pendidikan Islam yang berbasis moderasi Islam diharapkan mampu menjawab ragam justifikasi pendidikan islam sebagai produsen radikalisme dan terorisme di dunia. ${ }^{14}$ Beragam rekomendasi dan tindakan sudah dilakukan untuk mereformasi pendidikan Islam di Dunia, sebut saja di India sebagai bentuk skeptisisme terhadap proses dan hasil dari pendidikan yang dihasilkan dari lembaga dan institusi pendidikan Islam. Indonesia sebagai negara mayoritas muslim berkewajiban menjawab tuduhan dan keraguan tersebut melalui praktik pendidikan yang berlandaskan konsepsi moderasi dalam beragama baik secara pedagogik maupun andragogik. ${ }^{15}$ Memperbanyak diskusi publik terkait praktik pendidikan Islam di Indonesia menjadi salah satu upaya kementrian agama sebagai pilar kebijakan pendidikan Islam di Indonesia. Diskusi di ruang publik tersebut harus didasarkan pada landasan akurasi dan wacana sebagai upaya mereformasi apa yang kurang dipahami dalam praktik pendidikan Islam, karena jika gagal akan menguatkan justifikasi pendidikan islam di indonesia sebagai produsen teroris dan pesantren adalah salah satunya.

Berfokus pada konteks pesantren, tujuan penulisan artikel ini adalah 1) untuk mengeksplorasi terkait dengan pendidikan Islam dan memberikan pedoman untuk memperjelas aplikasinya di internal dan wacana eksternal; 2) untuk memetakan tipologi ekspresi pendidikan Islam di Indonesia melalui institusi pesantren; 3) untuk mengembangkan definisi yang lebih akurat yang dapat membantu menjembatani perbedaan antara wacana publik tentang pendidikan Islam di antara outsider dan insider; dan 4) untuk menjelaskan nilainilai pendidikan pesantren yang tidak bertentangan dengan nilai-nilai universal seperti kemanusiaan, perdamaian dan cinta kasih antar manusia tanpa memandang suku, agama, ras dan bangsa.

${ }^{13}$ Mukodi, "Pesantren dan Upaya Deradikalisasi Agama," Walisongo 23, no. 1 (2015): 89-112.

${ }^{14}$ Mualimul Huda, "Eksistensi Pesantren Dan Deradikalisasi Pendidikan Islam Di Indonesia (Menyemai Spirit Toleransi Dan Pendidikan Islam Multikultural),” FOKUS: Jurnal Kajian Keislaman Dan Kemasyarakatan 3, no. 1 (2018): 87-102.

15 Jasminto, "Urgensi Teori Andragogi Dalam Memperkuat Visi Moderat Islam di Indonesia," Proceedings of Annual Conference for Muslim Scholars (AnCoMS), Book Series 2 (2018): 643-51. 


\section{Diferensiasi Pendidikan Islam}

Masalah umum dalam perbedaan informasi pendidikan Islam di sebabkan pemahaman yang berbeda terhadap penggunaan kata Islam sebagai agama, kata sifat maupun kata benda. ${ }^{16}$ Islam sebagai agama dipahami berupa bentuk ajaran yang dibawa Muhammad saw yang ajarannya meliputi kebahagiaan dunia dan akhirat tentu melalui perdamaian dan cinta kasih antar manusia. Sebagai kata sifat islam memiliki makna segala karakter yang dilekatkan kepada objek yang menggunakan ajaran dan nilai-nilai islam sebagai landasan perilaku, sikap dan ideologinya sebagai pribadi, bangsa maupun perilaku kesehariannya. Sedangkan Islam sebagai kata benda lebih merujuk para penganut dan pemeluk ajarannya yang populer disebut muslim yakni mereka yang secara dejure dan defacto menyatakan islam sebagai agama yang dianutnya. Perbedaan istilah tersebut ketika melekat pada pemahaman pendidikan islam maka akan menghasilkan perbedaan definisi yang sangat tajam juga. Misal, pendidikan islam dipahami sebagai lembaga yang mengajarkan agama islam sebagai ideologi saja, ataupun pendidikan islam hanya dipahami sebagai lembaga pendidikan yang pesertanya muslim saja dan sebagainya. Persepsi demikian tidak seutuhnya salah, namun jika dikaitkan dengan isu terorisme dan radikalisme maka pemahaman tersebut akan mengerucut pada tuduhan pendidikan islam sebagai produsen radikalisme dan terorisme baik secara ideologis, praktis dan inspiratif.

Solusi paling sederhana dalam menyikapi perbedaan pemahaman terhadap istilah pendidikan islam yang didasarkan atas pemahaman islam tersebut dapat dilakukan dengan memilah istilah yang digunakan. Penggunaan istilah "islam" dalam pendidikan islam memiliki makna ideologis bahwa landasan praktik pendidikan sepenuhnya digali dari sumber hukum islam yakni qur'an dan sunnah. ${ }^{17}$ Pelaksanaan dalam lingkup pendidikan islam ini mencakup formal dan non formal dalam sebuah negara di seluruh dunia. Istilah "islami atau keislaman" bisa digunakan pada lingkup pendidikan yang mengambil sisi nilai agama islam sebagai praktik pendidikannya sehingga dimungkinkan peserta didik, instrumen pendidikan dan metode pendidikannya tidak diambil dari kajian sumber hukum islam namun adaptif dari berbagai sumber. ${ }^{18}$ Istilah "muslim" kemudian menjadi

\footnotetext{
${ }^{16}$ R. Abuy Sodikin, “Konsep Agama dan Islam,” Al-Qalam 20, no. 97 (April-June 2003): $1-20$.

${ }^{17}$ Muhammad Akmansyah, "Al-Qur'an dan Al-Sunnah Sebagai Dasar Ideal Pendidikan Islam,” Ijtimaiyya: Jurnal Pengembangan Masyarakat Islam 8, no. 2 (2015): 127-42.

18 Wahyuddin, "Sumber-Sumber Pendidikan Islam (Penalaran, Pengalaman, Intuisi, Ilham Dan Wahyu)," Inspiratif Pendidikan 7, no. 1 (2018): 133-46.
} 
pendidikan muslim bisa digunakan dalam memberikan definisi suatu lembaga pendidikan yang mengkhususkan muslim sebagai peserta didiknya, sebut saja pesantren masuk dalam kategori ini.

Konstruksi istilah pendidikan islam bisa menjelaskan perbedaan bentuk dan orientasi masing-masing lembaga yang mengklaim atau diklaim sebagai wujud pendidikan islam itu sendiri. ${ }^{19}$ Perbedaan bentuk pelaksanaan pendidikan islam bisa diamati dari ketiga tipologi tersebut sehingga masyarakat peneliti menjadi fokus dan mudah mengkategorikan mana lembaga yang dituduh banyak menghasilkan para teroris dan radikalis. Tanpa pengkategorian dalam bentuk tipologi akan menjadikan penilaian yang menyamaratakan seluruh pendidikan yang dilakukan oleh umat islam, tentu hal yang tidak benar. ${ }^{20}$ Perbedaan dalam praktik pendidikan islam menjadi penting dipahami karena tuduhan yang tidak benar akan memperuncing friksi antar kelompok, agama dan bangsa tentu jauh dari tujuan bersama yakni perdamaian dan keadilan seluruh umat manusia.

\section{Tipologi Pendidikan Islam di Indonesia}

Merujuk istilah general, pendidikan Islam, yang didasarkan atas agama, kata benda dan kata sifat maka akan ditemukan ragam tipologi pendidikan Islam di Indonesia. Pada tipologi pertama yang mendasarkan agama sebagai ideologi pendidikannya terdapat di dalamnya: pesantren, lembaga diniyah keagamaan, pengajian di surau dan masjid. Tipologi kedua, yang menjadikan nilai-nilai islam sebagai dasar praktik pendidikannya meliputi juga perguruan tinggi islam, madrasah, sekolah berbasis pesantren, madrasah diniyah. Tipologi ketiga, yang peserta didiknya hanya muslim saja antara lain pesantren, madrasah dan pengajian di surau dan masjid.

Tipologi secara umum tersebut masih menyisakan beberapa unsur pelaksanaan pendidikan islam yang diintegrasikan pada pendidikan formal di indonesia misal mata pelajaran pendidikan agama islam di sekolah, pendidikan agama islam di perguruan tinggi umum ${ }^{21}$ dan pendidikan agama islam melalui

\footnotetext{
${ }^{19}$ M. Mujab, "Studi Konstruksi Historis Pendidikan Islam Era Klasik Hingga Modern," El-Hikmah 9, no. 1 (2012): 40-56.

${ }^{20}$ Matrapi, "Tipologi Pemikiran Pendidikan Islam (Membangun Sebuah Paradigma Pendidikan Yang Mampu Menjadi Wahana Bagi Pembinaan Dan Pengembangan Peserta Didik)," Islamuna: Jurnal Studi Islam 5, no. 1 (2018): 1-15.

${ }^{21}$ Wage dan A. Sulaeman, "Pemberdayaan Pendidikan Agama Islam Di Sekolah Dan Perguruan Tinggi Umum," Islamadina: Jurnal Pemikiran Islam 17, no. 2 (2016): 31-40.
} 
penyuluhan keagamaan di masyarakat. ${ }^{22}$ Mata pelajaran pendidikan agama islam di sekolah merupakan rangkaian pembelajaran keagamaan yang meliputi akidahakhlak, al-qur'an hadits, fiqh dan sejarah kebudayaan islam yang materinya berdasar kajian kementrian agama dan dievaluasi oleh kementrian pendidikan. Perencanaan, pelaksanaan dan evaluasi yang dilakukan oleh pemerintah merupakan bentuk jaminan bahwa pelaksanaan pendidikan agama islam di sekolah bebas dari paham terorisme dan radikalisme. Pendidikan agama islam di perguruan tinggi umum juga demikian, proses perencanaan, pelaksanaan dan evaluasi dilakukan secara terbuka sehingga bisa dipastikan tidak ada muatan materi terorisme dan radikalisme. Sedangkan praktik pendidikan agama islam di masyarakat melalui penyuluh agama justru bertugas menyampaikan misi kementerian agama dalam menyebarkan misi moderasi beragama di masyarakat melalui penyuluh agama yang sudah terseleksi dan terpercaya.

Dari tipologi umum tersebut justru pesantren yang belum mampu menjawab tuduhan negatif sebagai penghasil terorisme dan radikalisme dikarenakan proses perencanaan, pelaksanaan dan evaluasi dilakukan secara tertutup dan bersifat lokal. Tuduhan negatif terhadap pesantren tersebut semakin kuat karena beberapa pelaku teror secara langsung berhubungan dengan pendidikan pesantren. Pelaku teror yang dihubungkan dengan pesantren secara faktual memang ada namun hanya kecil dari sepersekian persen pesantren yang ada di Indonesia. Pengalaman inilah yang mendorong pesantren untuk menjawab tuduhan dan berupaya mengklarifikasi dan mengeksplorasi proses dan tujuan pelaksanaan pendidikan islam di pesantren.

\section{Pendidikan Islam: Aplikasi dan Motivasi}

Definisi sederhana secara etimologis, pendidikan Islam dapat merujuk pada upaya yang dilakukan oleh masyarakat muslim dalam mendidik generasi mereka sendiri sebagai penyambung genealogi pengetahuan agama Islam, khususnya pengetahuan yang bersumber dari al-Qur'an dan Hadits. ${ }^{23}$ Pendidikan ini berlangsung di surau, masjid, sekolah, madrasah, universitas dan pesantren sebagai lembaga pendidikan agama islam khas di Indonesia. Di Pesantren, para pelajar baik laki-laki dan perempuan disebut sebagai santri yakni mereka yang mendapat bimbingan dan

${ }^{22}$ Nurkholipah, "Pengaruh Penyuluhan Agama Islam Terhadap Kesadaran Beragama Kepada Masyarakat," Irsyad: Jurnal Bimbingan, Penyuluhan, Konseling, Dan Psikoterapi Islam 5, no. 3 (2017): 287-310.

${ }^{23}$ Mappasiara, "Pendidikan Islam (Pengertian, Ruang Lingkup Dan Epistemologinya)," Inspiratif Pendidikan 7, no. 1 (2018): 47-60. 
pengasuhan seorang kyai di pesantren sebagai guru dalam aspek kognitif, afektif dan psikomotorik. ${ }^{24}$ Pendidikan di pesantren ini lebih mengambil peran subjektif dalam mempelajari dan mengajarkan islam sebagai agama sehingga interaksi antara komunitas lain agama minim sekali. Secara historis, pesantren dijelaskan memiliki posisi strategis dalam spektrum pendidikan nasional di masa kolonial, ini membuktikan bahwa peran pesantren yang semi tertutup dalam pergaulannya namun senantiasa menyimak isu terkini di luar lingkungan mereka. ${ }^{25}$ Peran pesantren dalam perjuangan kemerdekaan juga menjadi bukti bahwa materi kebangsaan yang secara administratif tidak tertulis di pesantren namun disampaikan dalam pembiasaan dan pembudayaan dalam kehidupan mereka.

Dalam konteks terkini, pesantren mengambil peran pada kancah pendidikan di Indonesia secara penuh. Keterlibatan pesantren dalam lingkup pendidikan nasional memunculkan istilah 'pesantren modern' yakni pesantren yang mengkonfigurasi kurikulumnya berdasar kurikulum nasional. ${ }^{26}$ Sisi lain dari pesantren modern ini adalah pesantren tradisional yakni pesantren yang masih mempertahankan kurikulumnya pada era awal pesantren. Pada perkembangan selanjutnya pesantren melibatkan diri secara administratif pada lingkup pendidikan nasional dengan mendirikan sekolah, madrasah dan universitas berbasis pesantren. Lembaga formal di bawah pesantren melaksanakan kurikulum nasional namun ada penambahan kurikulum lokal pesantren sebagai ciri khas pelaksanaan pendidikan islam yang bertipologi pendidikan islami. Praktik inilah yang kemudian memasukkan pesantren sebagai lembaga pendidikan islam di indonesia yang terlibat penuh dan bisa dievaluasi kurikulumnya secara terbuka oleh pemerintah dan masyarakat.

Motivasi pelaksanaan pendidikan pada pesantren di Indonesia secara garis besar menginduk pada organisasi masyarakat seperti Nahdlatul Ulama dan Muhammadiyah sebagai acuan pelaksanaan pendidikannya. ${ }^{27}$ Keterlibatan $^{2}$ organisasi masyarakat tersebut menjadi penanda juga bahwa pelaksanaan pendidikan pesantren masih dijiwai dengan posisi sosial dan politis organisasi

${ }^{24}$ Ahmad Muhakamurrohman, "Pesantren: Santri, Kiai, dan Tradisi," Ibda` : Jurnal Kajian Islam Dan Budaya 12, no. 2 (Juli 2014): 109-18.

25 Jasminto, "Sumbangsih Pesantren dalam Historiografi Nusantara Sebuah Kajian Pendidikan Islam,” Jurnal Islam Nusantara 1, no. 1 (2017): 61-71.

${ }^{26}$ Abdul Tolib, "Pendidikan di Pondok Pesantren Modern," Risâlah, Jurnal Pendidikan Dan Studi Islam 2, no. 1 (2015): 60-66.

${ }^{27}$ Muttaqin, "Pemikiran dan Manajemen Pendidikan NU dan Muhammadiyah," Nur El-Islam : Jurnal Pendidikan Dan Sosial Keagamaan 4, no. 1 (April 2017): 1-39. 
masyarakat juga. Posisi sosial dan politis ini juga menjadi jaminan bahwa pendidikan pesantren masih mengusung pemahaman islam yang moderat bukan teroris dan ekstrimis. Nahdlatul Ulama sebagai ormas keagamaan terbesar di Indonesia mengusung jargon 'islam nusantara' menyiratkan semangat moderasi beragama yang teraplikasi pada lembaga pendidikan yang terafiliasi di dalamnya. ${ }^{28}$ Muhammadiyah dengan jargon 'islam berkemajuan' berposisi sebagai organisasi masyarakat terbesar kedua di Indonesia lebih berkonsentrasi dalam mendirikan berbagai sekolah dan perguruan tinggi, tentu sisi moderasi beragama menjadi landasan pendirian lembaga-lembaga pendidikan yang didirikannya. ${ }^{29}$ Kebangsaan, keragaman dan keagamaan menjadi motivasi kedua organisasi masyarakat tersebut untuk terlibat dalam kancah pendidikan nasional di Indonesia.

\section{Pesantren: Insider dan Outsider}

Pesantren merupakan lembaga pendidikan yang menampung pelajar Muslim penuh waktu menjalankan program pendidikan yang berorientasi penerapan pengetahuan agama dalam kehidupan. ${ }^{30}$ Pesantren memiliki jangkauan yang lebih luas daripada pembelajaran di surau dan masjid, mahupun mata pelajaran pendidikan agama islam di sekolah, madrasah dan perguruan tinggi. Pesantren digambarkan oleh umat Islam sebagai sekolah islam di mana pendidik memberikan pendidikan "islam", "islami” dan "muslim”. Pesantren dapat disebut pendidikan "islam" karena secara ideologis dan praktis pesantren memberikan pendidikan kepada peserta didiknya pandangan agama Islam secara menyeluruh. ${ }^{31}$ Di Pesantren juga seluruh pergaulan, etika dan moral berdasar nilai-nilai agama Islam sehingga Pesantren masuk juga pada kategori pendidikan “islami”. Peserta didik di pesantren keseluruhannya merupakan para santri yang beragama islam dengan demikian pesantren juga bisa disebut pendidikan "muslim".

Dalam kaca pandang umat Islam, Pesantren merupakan lembaga yang komprehensif dalam melaksanakan pendidikan Islam dikarenakan pelaksanaannya yang penuh waktu dan kurikulum yang padat. Pesantren

${ }^{28}$ Ahmad Agis Mubarok dan Diaz Gandara Rustam, "Islam Nusantara: Moderasi Islam di Indonesia," Journal of Islamic Studies and Humanities 3, no. 2 (2018): 153-68.

${ }^{29}$ Muhammad Kahfi, "Peranan Muhammadiyah Sebagai Gerakan Islam Berkemajuan di Era Modern," Al-Risalah 11, no. 2 (2020): 110-28.

${ }^{30}$ Imam Syafe'i, "Pondok Pesantren: Lembaga Pendidikan Pembentukan Karakter," AlTadzkiyyah: Jurnal Pendidikan Islam 8, no. 1 (2017): 61-82.

31 B. Marjani Alwi, "Pondok Pesantren: Ciri Khas, Perkembangan, Dan Sistem Pendidikannya," Lentera Pendidikan 16, no. 2 (2013): 205-19. 
mendasari pembelajarannya dengan kurikulum dan metode yang khas, sebut saja bandongan, sorogan, kitab kuning dan halaqoh. ${ }^{32}$ Bandongan merupakan metode khas dalam pembelajaran yang peran pendidik memberikan keterangan kitab kuning yang berbahasa arab diberi arti dengan bahasa lokal kemudian dijelaskan. Sorogan lebih kepada pembelajaran aktif dimana santri diminta membaca kitab kuning di hadapan guru kemudian menjelaskan maknanya secara naratif. Adapun halaqoh sebagai bentuk metode pembelajaran di mana guru berposisi di tengah sedang murid mengitarinya untuk mendengarkan ceramah dan kajian guru.

Pembelajaran di pesantren murni kajian keagamaan yang dipadukan dengan budaya lokal. ${ }^{33}$ Bentuk kurikulum pesantren menekankan keterampilan dalam praktik keagamaan dan didukung kompetensi bermasyarakat sebagai bekal kelak pulang dari pesantren dan terjun di tengah masyarakat. ${ }^{34}$ Pesantren sudah lama menjadi lembaga pendidikan di Indonesia, ini mengindikasikan keberadaan pesantren bukan anti pemerintahan justru mitra strategis dalam pengembangan sumber daya manusia. Keterpaduan kurikulum pesantren menjadi modal kuat praktik moderasi keberagamaan di Indonesia yang penduduknya majemuk dan plural dengan ribuan suku dan aneka agama. ${ }^{35}$

Kajian di pesantren meliputi teologi hingga fiqh yang mengambil dari beragam aliran dan madzhab tentu setelah melalui adaptasi dari para kiai pendahulu. Pemilahan kurikulum berdasar pendapat ulama yang moderat menghadirkan kajian di pesantren lebih adaptif terhadap budaya lokal tentu ini yang membedakan dengan aliran ekstrimisme atau radikalisme islam. ${ }^{36}$ Pengambilan aliran dan madzhab tertentu sebagai bahan penyusunan kurikulum di pesantren didasarkan pada pendekatan tradisional yang lebih praktis dan adaptif terhadap kebutuhan masyarakat di daerahnya masing-masing sehingga

32 Nia Indah Purnamasari, "Konstruksi Sistem Pendidikan Pesantren Tradisional Di Era Global; Paradoks Dan Relevansi," EL-BANAT: Jurnal Pemikiran Dan Pendidikan Islam 6, no. 2 (Desember 2016): 73-91.

33 Mukhibat, "Meneguhkan Kembali Budaya Pesantren dalam Merajut Lokalitas, Nasionalitas, Dan Globalitas," KARSA: Journal of Social and Islamic Culture 23, no. 2 (2015): 177-92.

${ }^{34}$ Ali Imron, Hamzah dan Agus Yudiawan, "Integrasi Kurikulum Pondok Pesantren Dalam Peningkatan Pemahaman Agama Islam Di SMP IT Nurul Yaqin Kabupaten Sorong," Al-Fikr: Jurnal Pendidikan Islam 3, no. 1 (2017): 1-9.

35 Hermanto Halil, "Inovasi Kurikulum Pesantren dalam Memproyeksikan Model Pendidikan Alternatif Masa Depan,” “Ulumuna: Jurnal Studi Keislaman 1, no. 2 (2015): 14668.

${ }^{36}$ Husnul Khotimah, "Internalisasi Moderasi Beragama Dalam Kurikulum Pesantren," Rabbani: Jurnal Pendidikan Agama Islam 1, no. 1 (Maret 2020): 62-68. 
warna pesantren pun menjadi beragam. Teologi hingga fiqh memang menjadi kajian utama pesantren di samping pembelajaran berkehidupan seperti berkebangsaan dan bermasyarakat. Sehingga pendidikan pesantren untuk dituduh sebagai penyemai radikalisme tentu kesalahan, jika ada, bisa dipastikan pesantren (mengatasnamakan diri pesantren) yang tidak berkurikulum pesantren.

Sebagai lembaga pendidikan yang penuh waktu dan berasrama, pesantren sering mendapat tuduhan sebagai penyemai paham radikalisme dan ekstrimisme islam. Tuduhan yang disampaikan oleh mereka yang tidak mengenal pesantren atau outsider ini didasarkan pada penampakan pesantren yang tertutup. Pesantren memiliki kesan tertutup terhadap evaluasi pihak luar bukan karena mengajarkan ideologi yang berbahaya dan rahasia tetapi lebih kepada kemerdekaan dalam belajar yang diinginkan. Pendapat mereka yang belum mengenal pesantren mengesankan pesantren sebagai lembaga yang kolot, tertutup dan tidak mau diatur dikarenakan ketertutupan pesantren atas evaluasi pihak luar pesantren. Peristiwa 11 September 2009 menjadi titik balik berbagai unsur peneliti mengungkap sisi pesantren yang bertujuan mengklarifikasi keberadaan pesantren sebagai lembaga yang menyemai bibit-bibit radikalisme. Beruntungnya, saat ini pesantren sangat terbuka kepada para peneliti sehingga ragam testimoni ilmiah menguatkan keberadaan pesantren justru penguat paham moderasi beragama.

Pesantren mengambil nama-nama berbahasa arab sebagai penanda tujuan dan motivasinya semisal Darul Ulum, al-Falah, Madrasatul Quran ataupun namanama tokoh muslim hingga nama desa setempat sebagai bentuk menyatunya pesantren dengan budaya lokal seperti Tebuireng. Saat ini komunikasi pesantren sudah sangat terbuka hingga komunitas lintas iman. Seperti pesantren Tebuireng sering mengadakan acara bertajuk kebangsaan, pluralisme hingga kerukunan antar umat beragama ini menunjukkan komunikasi pesantren yang semakin terbuka terhadap komunitas masyarakat lainnya di luar pesantren. ${ }^{37}$

\section{Nilai-nilai Pendidikan di Pesantren}

Akhlak Karimah

Pendidikan tentang Islam di pesantren berkembang sesuai dengan zamannya. Buku pelajaran dan kurikulum Pesantren sudah banyak pula yang memakai karyakarya kontemporer tentu dengan tidak meninggalkan tradisi turats. Penekanan pada ketercapaian kurikulum tersebut didasarkan atas perilaku santri yang

37 Syamsul Huda Rohmadi, "Pendidikan Islam Inklusif Pesantren ( Kajian Historis Sosiologis Di Indonesia ),” FIKROTUNA 5, no. 1 (Juli 2017): 1-17. 
mengedepankan nilai karakter seorang muslim yang berbasis akhlak karimah. ${ }^{38}$ Akhlak Karimah yang didefinisikan berupa perilaku yang telah membudaya pada diri seseorang merupakan rangkaian watak, sikap dan kebiasaan yang didasarkan pada al-qur'an hadits sebagai landasannya. Akhlak Karimah merupakan perwujudan etika dan moral yang ada di lingkungan pesantren, merupakan perilaku yang selalu diajarkan dan praktekkan dalam kehidupan sehari-hari. ${ }^{39}$

Penerapan akhlak karimah di pesantren didasarkan pada praktik ibadah yang berkelanjutan, dengan sholat berjamaah, kegiatan pengajian, doktrin keagamaan yang secara kontinu dijalankan dan dievaluasi secara berkala. ${ }^{40}$ Praktik pembiasaan tersebut diharapkan mampu membentuk kesadaran para santri nantinya dalam melaksanakan sholat lima waktu berjamaah, memimpin shalat dan mempraktikkan amalan-amalan sunnah. Akhlak karimah santri ini yang nantinya memunculkan sikap keikhlasan, kesederhanaan, berdikari dan optimis dalam menjalani kehidupan bermasyarakat.

\section{Cinta Agama, Bangsa dan Negara}

Santri yang pada akhirnya hidup bermasyarakat dibekali dengan prinsip "hubbul wathan minal iman" (cinta negara sebagian dari iman) sebagai dasar cara hidup di masyarakat. Pengertian cinta negara sebagian dari iman memiliki makna mendalam dalam menautkan keagamaan dan kebangsaan. ${ }^{41}$ Ukhuwah Wathaniyah yang selanjutnya disebut cinta bangsa dan negara merupakan rangkaian yang berkelindan dengan cinta agama yakni pemahaman terhadap agama yang menghargai kebangsaan sebagai unsur bermasyarakatnya. Cinta bangsa dan negara secara tidak langsung menguatkan pemahaman santri atas perbedaan dan keragaman bangsa Indonesia, nilai ini termasuk moderasi dalam beragama. ${ }^{42}$

${ }^{38}$ Muhammad Rizal, Muhammad Iqbal dan Najmuddin, "Model Pendidikan Akhlaq Santri Di Pesantren Dalam Meningkatkan Akhlaq Siswa Di Kabupaten Bireuen," Nadwa 12, 1 (2018): 89-116.

${ }^{39}$ Zainal Arifin, "Budaya Pesantren Dalam Membangun Karakter Santri," Al Qodiri : Jurnal Pendidikan, Sosial Dan Keagamaan 6, no. 1 (April 2014): 1-22.

${ }^{40}$ Badiusman Badiusman, "Pembinaan Disiplin Beribadah Santri di Pondok Pesantren Iqra' Barung-Barung Balantai Kecamatan Koto XI Tarusan Kabupaten Pesisir Selatan," Ruhama: Islamic Education Journal 1, no. 1 (Mei 2018): 13-23.

${ }^{41}$ Hamidulloh Ibda, "Relasi Nilai Nasionalisme Dan Konsep Hubbul Wathan Minal Iman Dalam Pendidikan Islam,” International Journal Ihya' 'Ulum Al-Din 19, no. 2 (2017): 245-270.

${ }^{42}$ Nur Rofiq, "Telaah Konseptual Implementasi Slogan Hubb Al-Wathan Min Al-Iman KH. Hasyim Asy'ari Dalam Pendidikan Karakter Cinta Tanah Air," Jurnal Keluarga Sehat Sejahtera 16, no. 32 (2018): 44-52. 
Adanya cinta bangsa dan negara secara tidak langsung adalah praktik moderasi beragama melalui penghargaan perbedaan sesama manusia (hubbul basyariah).

Metode dalam pelaksanaan pendidikan kebangsaan di pesantren melalui keteladanan, latihan dan pembiasaan, melalui ibrah (mengambil pelajaran dari kisah), melalui mauizah (nasehat) dan targhib wa tahdhib. ${ }^{43}$ Metode yang aplikatif dalam penerapan pendidikan kebangsaan di pesantren dilakukan secara kontinu hingga menjadi karakter santri dalam berkehidupan. Metode ini memiliki dampak signifikan terhadap peran santri dalam praktik kebangsaan di era awal kemerdekaan, sebut saja resolusi jihad pada 22 Oktober 1945 merupakan bentuk keberhasilan metode tersebut. ${ }^{44}$ Gerakan santri dalam kegiatan kebangsaan ${ }^{45}$ menegaskan bahwa ajaran yang dipraktikan di pesantren bukan yang dituduhkan sebagian media barat bahwa pesantren tidak adaptif dan inklusif terhadap ideologi asing yang membuatnya menjadi lembaga radikal dan ekstrimis. Kebalikan dari tuduhan tersebut, melalui metode yang sesuai dengan kondisi pesantren berhasil menumbuhkan jiwa kebangsaan yang lekat pada generasi pesantren selanjutnya, sebut saja Nahdlatul Ulama yang menjadi mitra strategis pemerintah dalam mempraktikkan moderasi beragama di Indonesia.

Dinamika pesantren dalam perannya sebagai lembaga pendidikan islam yang menjadi garda moderasi beragama terdepan menjadikan pesantren tumpuan kebijakan pemerintah. Melalui pendidikan pemerintah menjalankan misi kerukunan antar umat beragama tentu yang menjadi kuncinya adalah lembaga keagamaan yang memiliki peserta didik terbanyak tentu pesantren adalah yang dimaksud. Keselarasan pesantren dengan misi kerukunan antar umat beragama terletak pada praktik moderasi beragama yang dijadikan dasar pembelajaran keagamaan di pesantren.

\section{Kapita Selekta Pesantren di Kajian Global}

${ }^{43}$ Ali Mursyid, "Pendidikan Nilai-Nilai Kebangsaan Di Pesantren : Riset Di Pesantren Ashidiqiyah Jakarta Barat," MISYKAT: Jurnal Ilmu-Ilmu Al-Quran, Hadist, Syari'ah Dan Tarbiyah 3, no. 2 (2018): 125-56.

44 Inggar Saputra, "Resolusi Jihad: Nasionalisme Kaum Santri Menuju Indonesia Merdeka," Jurnal Islam Nusantara 3, no. 1 (2019): 205-37.

45 Muhammad Bimo Sakti, Irawan Suntoro dan Yunisca Nurmalisa, "Peranan Pesantren Dalam Menumbuhkan Wawasan Kebangsaan Kepada Santri," Jurnal Kultur Demokrasi 5, no. 12 (2018): 10-20. 
Peradaban Barat yang digunakan untuk mengajar sejak dini versi "sejarah dunia" di sekolah-sekolah sering membatasi informasi islam terhadap latar belakang tentang peristiwa dalam sejarah Eropa, seperti Perang Salib, jatuhnya Konstantinopel, atau Reconquista. Pembahasan Islam di Eropa terbatas pada rubrik-rubrik timur tengah yang sangat terbatas, siswa hanya menerima sedikit lebih dari pandangan sepintas pada lanskap gurun dan cakupan masyarakat Muslim. ${ }^{46}$ Dikotomi ini menempatkan Islam dikenal hanya pada masyarakat muslim yang mengikuti peradaban modern saja yang dikenal oleh masyarakat barat. Kajian sejarah awal yang ditulis secara global membutuhkan banyak penjelasan, sayangnya peran ini banyak diambil sarjana barat yang secara umum meninggalkan perspektif islam dalam penulisannya. ${ }^{47}$ Ketidakakuratan dan inkonsistensi penulisan sejarah dengan meninggalkan perspektif islam ini di kemudian hari memperlebar gap generasi muda dalam memahami Islam terlebih islam yang tampil di lingkungan mereka yang anti moderasi.

Selama dua dekade, pengajaran tentang agama-agama dunia telah menjadi bagian dari kurikulum sekolah umum. Pengajaran agama masuk dalam kajian studi sosial yang bersifat humaniora memberikan akses kepada para pelajar dan peneliti untuk memperdalam agama melalui berbagai studi. ${ }^{48}$ Reformasi kurikulum di berbagai negara menempatkan pembelajaran agama pada kelas agama-agama besar dunia, termasuk Islam, di kelas geografi dan sejarah dunia. Masuknya islam pada kajian keilmuan memberikan sedikit ruang informasi terhadap perspektif mereka yang tidak mengenal islam sebelumnya terlebih mengenal islam hanya melalui media sosial.

Pada kajian yang lebih luas di beberapa negara eropa menyimpulkan bahwa mengajar tentang agama dibutuhkan dokumen standar negara yang dikembangkan berbasis moderasi, secara luas di berbagai jenjang pendidikan. ${ }^{49}$ Faktor paling penting dalam mempromosikan pengajaran tentang agama di sekolah umum mengharuskan perubahan kurikulum yang lebih adaptif terhadap konteks terkini yang menyandingkan persamaan, kemanusiaan dan kebebasan

${ }^{46}$ Rofik, "Nilai Pembelajaran Sejarah Kebudayaan Islam dalam Kurikulum Madrasah," Jurnal Pendidikan Agama Islam 12, no. 1 (2015): 15-30.

${ }^{47}$ Wasito, "Respon Barat Terhadap Islam Sebagai Sumber Peradaban," Jurnal Pemikiran Keislaman 24, no. 2 (2013): 48-58.

${ }^{48}$ Husin, "Pendidikan Agama Islam di Amerika Serikat (Lembaga Pendidikan Islam)," Al-Madrasah: Jurnal Pendidikan Madrasah Ibtidaiyah 2, no. 2 (Januari-Juni 2018): 48-58.

${ }^{49}$ Dedi Napitupulu and Syawal Fahmi, "Pendidikan Islam Muslim Minoritas (Kasus Di Eropa Barat),” Belajea; Jurnal Pendidikan Islam 5, no. 1 (May 2020): 37-50. 
sebagai unsur utama kehidupan. Menyikapi ini, kajian keagamaan islam mereformula bahasan-bahasan keagamaan lebih updatable dan mudah dipahami secara global.

Pesantren hadir sebagai opsi pengajaran agama secara konstitusional yang berbasis nilai moderasi. Pedoman dalam meningkatkan tingkat pemahaman peserta didik dalam kompetensi berkehidupan yang lebih menghargai perbedaan menjadi penguat rujukan ke pesantren. Tuntutan atas persamaan, kemanusiaan dan kebebasan dalam berinteraksi antar umat beragama tentu mudah dipahami lingkungan pesantren sebagai lembaga pendidikan islam yang berbasis moderasi. Pedoman dan implementasi pendidikan islam yang berbasis moderasi akan mudah disusun dari pengalaman pelaksanaan pembelajaran keagamaan di pesantren, hal inilah nantinya yang akan menempatkannya sebagai lembaga pendidikan yang akomodatif dan moderat.

Pesantren sebagai lembaga pendidikan islam yang menjadikan turats sebagai buku teks pelajaran berusaha meningkatkan akurasi hasil belajar dengan praktik berkesinambungan. Penggambaran buku teks dalam keimanan, praktik ibdah, kisah sejarah dan budaya melalui berbagai kutipan sejarah bertujuan menggambarkan islam secara utuh baik persinggungannya dengan agama lainnya di dunia. Interpretasi sejarah melalui teks ini diharapkan mampu menanamkan pemahaman moderat secara konsisten, dikombinasikan dengan akurasi faktual yang ada.

\section{Konsepsi Teoritis tentang Pendidikan Islam}

Pendidikan dalam semangat Islam adalah konsepsi 'iqra' sebagai perintah belajar yang ruang lingkupnya mencakup pendidikan secara universal, bukan tentang agama saja. ${ }^{50}$ Pada tahapan praktik, pendidikan islam seringkali berkonotasi pendidikan yang khusus diperuntukkan umat islam saja sehingga bersifat eksklusif. Disamping bersifat tertutup pendidikan islam juga dikonotasikan menghilangkan pengetahuan sekuler dan hanya berkonsentrasi pada pendidikan agama semata. Kedua pemahaman tersebut yang memunculkan kecurigaan mereka yang tidak mengenal islam dengan menuduh kurikulum pendidikan islam menanamkan kebencian kepada masyarakat luar islam.

Konsep pendidikan Islam tidak dapat direduksi menjadi stereotip dengan sifat eksklusif dan pendidikan agama ansigh, yang berpedoman secara kaku pada

50 Colle Said, "Paradigma Pendidikan dalam Perspektif Surah Al-Alaq Ayat 1-5," Hunafa: Jurnal Studia Islamika 13, no. 1 (2016): 91-117. 
peradaban islam masa lalu. Pendidikan Islam tentu saja bagian dari tradisi sejarah, tetapi itu bukan kebalikan dari modernitas, nilai-nilai demokrasi atau tradisi barat. Stereotip terhadap pendidikan islam disebabkan pula dari identifikasi berlebihan dunia barat terhadap sejarah agama, konteks gereja dan pertentangan sains yang menyudutkan islam sebagai antitesisnya, kekeliruan ini kemudian ditetapkan sebagai pedoman universal. Pendidikan islam yang bercoran eksklusif secara kelembagaan memang ada, namun corak inklusif lebih dominan dalam kurikulum pendidikan islam lintas sejarah. ${ }^{51}$

Persepsi sebagian masyarakat barat berbeda dengan konsepsi Islam dalam memaparkan terminologi pendidikan yang mengaitkan dengan tradisi belajar masyarakat muslim secara umum tanpa membedakan sumber pengetahuan, konteks agama dan perdebatan sains. Islam menyatakan pendidikan sebagai tugas utama seorang Muslim, pria atau wanita sebagai media mengenal Tuhan melalui proses belajar dan mengajar. ${ }^{52}$ Perintah agama dalam belajar tersebut terdokumentasikan dalam al-Qur'an yang menjadi pedoman muslim dalam membangun geneologi keilmuan secara transmisi antargenerasi. Tradisi keilmuan yang menekankan urgensi membaca dan menulis sebagai tradisi belajar dikuatkan pula oleh ajaran Muhammad saw yang ditekankan sebagai prioritas sosial.

Seluruh kegiatan Muhammad saw didasarkan pada panduan al-Qur'an yang diturunkan berdasarkan kehidupan masyarakat, secara umum bisa disebut sebagai pendidikan sosial kemasyarakatan. Turunnya ayat al-Qur'an secara berangsur hingga 23 tahun masa kenabian mengindikasikan kehidupan Nabi sebagai materi sekaligus media pendidikan islam. ${ }^{53}$ Kehidupan Nabi sebagai sumber sekaligus media pendidikan islam dikarenakan selain ayat-ayat al-Qur'an kata-kata dan tindakan Nabi dicatat pula sebagai sumber hukum islam (al-Hadits). Perilaku Nabi yang dibukukan dalam catatan hadits di berbagai buku hadits dijadikan pula sebagai sumber hukum islam, dari situ memunculkan ragam disiplin ilmu misal tafsir al-Qur'an, takhrij hadits, ushul fiqh dan sebagainya yang di kemudian hari menjadi kurikulum pendidikan islam. ${ }^{54}$

\footnotetext{
${ }^{51}$ Moh. Mizan Habibi, “Corak Pendidikan Islam Inklusif,” El-Tarbawi 10, no. 1 (2017): 35-48.

52 Oktrigana Wirian, "Kewajiban Belajar dalam Hadis Rasulullah SAW.," Jurnal Sabilarrasyad 2, no. 2 (2017): 41-54.

53 Desti Widiani, "Konsep Pendidikan dalam Perspektif Al-Qur'an,” Murabby: Jurnal Pendidikan Islam 1, no. 2 (September 2018): 185-96

${ }^{54}$ Nurmadiah, "Kurikulum Pendidikan Agama Islam," Al-Afkar: Jurnal Keislaman $\mathbb{E}$ Peradaban 2, no. 2 (2014) : 41-54.
} 
Literatur sejarah peradaban islam pada periode Abbasiyah menunjukkan tradisi melek huruf telah mapan di banyak daerah di daerah kekuasaannya. Tradisi literasi ini yang memperluas kajian pendidikan Islam dalam berbagai kegiatan literasi melalui penerjemahan, penulisan buku penjelas (pensyarahan) dan pembukuan berbagai bidang keilmuan baik agama dan sains, bahkan filsafat. Masa Abbasiyah ini menjadi tonggak awal bagaimana pendidikan islam bukan serta merta pendidikan agama saja, namun segala disiplin ilmu sehingga lebih sesuai dengan istilah "Pendidikan Islami. Pada masa ini pula pengetahuan humaniora berkembang pesat mewarnai peradaban islam dengan berdasar pada tradisi ilmiah sehingga berkembang pula bidang pelayaran, navigasi, astronomi, perdagangan, peternakan dan pertanian. ${ }^{55}$ Perkembangan pendidikan yang pesat ini tidak lepas dari dukungan para khalifah menyediakan dana terhadap pengembangan pendidikan dan hukum Islam. Peran serta para khalifah ini tentu menjadi motivasi bagi para ilmuwan untuk menetapkan standar tinggi dalam pencapaian tujuan pembelajaran baik secara teoritis maupun praktis. Pengetahuan-pengetahuan praktis yang menonjol seperti penghitungan waktu dan kalender, penetapan kiblat, perhitungan warisan, berat, dan ukuran. Kesejahteraan rakyat yang berdampak pada tradisi literasi menghasilkan terbentuknya institusi pendidikan yang memajukan ide tentang Pendidikan Islam jauh melampaui zamannya hingga menjadi dasar dan pedoman hingga hari ini.

Dinamika pendidikan islam dari masa nabi hingga sekarang menjadi acuan penilaian pendidikan islam yang komprehensif. Secara garis besar apa yang didapatkan dari penggalian sejarah pendidikan islam memberikan fakta bahwa tidak ada pemisahan agama dan sains dalam belajar sehingga praktik sekularisme itu tidak terbukti. Pendidikan islam dalam konteks ini harus dipahami sebagaimana dalam kebanyakan tradisi yang beradab dalam sejarah dunia yang menjadikan ilmu pengetahuan sebagai alat mewujudkan perdamaian secara universal bukan sebaliknya. Terdapat identifikasi terhadap metode belajar yang berbeda dengan tradisi barat bukan berarti bentuk permusuhan, hal itu tidak lebih karena di beberapa disiplin ilmu keislaman mensyaratkan metode belajar secara hierarkis dalam pemahaman agama yang tentu tidak dikenal dalam tradisi barat. Perbedaan ini juga disebabkan konsepsi epistemologis yang berbeda dalam mencari kebenaran, islam menekankan revelasi sebagai sumber kebenaran utama. Penekanan revelasi sebagai sumber kebenaran mengacu kepada al-Qur'an dan

${ }^{55}$ Maryamah, "Pendidikan Islam Masa Dinasti Abbasiyah," Tadrib: Jurnal Pendidikan Agama Islam 1, no. (2015): 47-65. 
Hadits yang menjadi kebenaran absolut, meski pada penafsiran ada perbedaan dalam interpretasi maknanya.

Penggambaran pengetahuan yang masih global dalam al-Qur'an dan hadits membutuhkan penjelasan melalui ijtihad, observasi dan eksperimen yang tentu mengacu pada standarisasi ilmiah. Meski wahyu sebagai sumber hukum islam, keberadaan penelitian ilmiah sebagai penjelas makna senantiasa dibutuhkan, ini membuktikan secara materi pendidikan islam memakai tradisi ilmu pengetahuan secara umum. ${ }^{56}$ Bidang kajian utama dalam al-Qur'an sebagai sumber hukum Islam meliputi aqidah, ibadah dan 'ilm. Penegasan umat islam untuk belajar ilmu pengetahuan dinyatakan secara tegas oleh Muhammad saw agar umat islam berpikir secara mandiri tentang hal-hal kehidupannya, keterampilan dan kebutuhan penopang perkara duniawi. Perintah tersebut memberikan penjelas bahwa dalam pendidikan islam musti melibatkan keterampilan yang mendukung kehidupan manusia di dunia, jika kontekskan saat ini tentu bidang teknologi, ekonomi, politik, pertanian dan sebagainya. Proses pencarian umat islam atas apa yang belum dijelaskan dalam hukum islam serta ruang mana yang diperbolehkan untuk dikembangkan sebagai adaptasi pada konteks kehidupan inilah yang disebut ijtihad.

Pada sisi yang lain, al-Qur'an menjadi sumber inspirasi bagi banyak bidang pengetahuan, baik sebagai aspek filosofis hingga fenomena alam. Keberadaan al-Qur'an tersebut menjadi motivasi dalam pendidikan Islam dengan memaknai din (agama) memiliki hubungan yang kuat dengan intelektual dan kehidupan beradab. Dien tidak merujuk pada institusi manusia, tetapi pada kondisi keberadaan islam sebagai sebuah kepercayaan. Konsep din ini memiliki makna yang menggarisbawahi hubungan antara kehidupan spiritual, intelektual, dan beradab. Jadi, agama dan pendidikan disatukan dalam usaha manusia untuk mengetahui dan memuliakan Sang Pencipta, dan mencari ilmu dan memanfaatkannya secara bermanfaat di masyarakat. Ini pengetahuan dikembangkan dan ditransmisikan untuk memastikan keberlanjutan masyarakat yang beradab.

Konsep pengetahuan dalam tradisi Islam disandarkan pada kata 'ilm yang memiliki makna pengetetahuan yang merujuk pada mereka yang menguasainya disebut alim (ulama). Tradisi keilmuan Islam tidak termasuk penobatan dalam sebuah kelulusan jenjang studi, tetapi menganugerahkan status alim atas mereka

56 Abd. Rozak, "Al-Quran, Hadis, dan Ijtihad Sebagai Sumber Pendidikan Islam," Fikrah: Journal of Islamic Education 2, no. 2 (December 2018): 85-101. 
yang penilaian atau pengetahuannya dianggap layak. ${ }^{57}$ 'Ulama' telah membentuk kelompok sosial yang sangat berpengaruh sepanjang sejarah Peradaban Muslim, dalam peran mereka sebagai pendidik, ahli hukum dan sarjana. Pemberian kehormatan kepada 'Ulama' oleh pemerintah muslim dalam sejarah peradaban islam menegaskan peran mereka dalam penyatuan keyakinan, praktik Islam dan dalam mempertahankan tradisi melek huruf dalamnya masyarakat muslim.

Konsep tambahan dari budaya Muslim dan bahasa Arab yang memberi sumbangsih pada aspek sosial pendidikan Islam adalah adab. Pengertian adab sebagai kebiasaan atau norma perilaku yang diturunkan dari generasi ke generasi meliputi segala perilaku kebaikan untuk dijalankan umat islam. ${ }^{58}$ Seiring dengan berkembangnya peradaban Muslim, kata adab memunculkan pengertian "kualitas jiwa yang tinggi, pendidikan yang baik, urbanitas dan kesopanan," kedua kata terakhir mengacu pada perilaku yang digunakan dalam tradisi pendidikan yang bisa beradaptasi dengan tradisi di luar islam. Konsep tersebut bergabung ke dalam sistem pendidikan islam, di mana adab memperoleh makna intelektual: jumlah pengetahuan yang membuat seseorang sopan dan "sopan" dalam budaya sekuler. Untuk menjadi mu'addab, seseorang harus belajar ilmu retorika, tata bahasa, leksikografi, metrik, dan fasih dalam puisi, sastra, dan ilmu pengetahuan. Konsep adab mendukung penyempurnaan estetika kehidupan beradab, dan merupakan bagian integral dari pendidikan dalam semangat Islam.

Konsep tarbiyah yang holistik lebih sesuai dengan konsepsi pendidikan moral yang meliputi cara memperoleh pengetahuan, etika, dan pandangan dunia moral berlandaskan al-Qur'an dan Hadits. ${ }^{59}$ Kerangka moral bagi seorang Muslim adalah niat baik, dan untuk memastikan bahwa sarana untuk mencapai kebaikan atau menghindari kejahatan ada dalam diri mereka secara benar. Pendidikan memberi seseorang pengetahuan untuk mengenali tugas, fondasi moral dalam mengetahui apa yang harus dilakukan oleh manusia secara individu dan sosial. Pendidikan Islam menggabungkan aspek-aspek tersebut dalam lingkup kurikulum pendidikan islam yang dilaksanakan secara tradisi turun temurun antar generasi.

${ }^{57}$ Surahman Amin dan Ferry Muhammad Siregar, "Ilmu dan Orang Berilmu dalam AlQur'an: Makna Etimologis, Klasifikasi, dan Tafsirnya," Empirisma: Jurnal Pemikiran dan Kebudayaan Islam 24, no. 1 (2015): 131-141.

${ }^{58}$ Toha Machsun, "Pendidikan Adab, Kunci Sukses Pendidikan," EL-BANAT: Jurnal Pemikiran Dan Pendidikan Islam 6, no. 2 (Desember 2016): 102-13.

${ }^{59}$ Muhammad Arya Dana, "At-Tarbiyah Sebagai Konsep Pendidikan Dalam Islam," INOVATIF: Jurnal Penelitian Pendidikan, Agama Dan Kebudayaan 6, no. 1 (Februari 2020): 88-104. 
Dalam belajar tentang din, umat islam akan belajar untuk menjalankan tugas-tugas iman dan bertindak sesuai dengan prinsip etika dan moral, bertanggung jawab secara sosial dan berusaha mewujudkan kehidupan sosial yang beradab. Pernyataan misi salah satu pesantren di Indonesia ini mengungkapkan tujuan yang harmonis pendidikan dan pengabdian iman dan nilai-nilai sosial: Mendidik dan mengembangkan generasi mukmin-muslim yang berbudi tinggi, berbadan sehat, berpengetahuan luas, dan berpikiran bebas, serta berkhidmat kepada masyarakat. Mengajarkan ilmu pengetahuan agama dan umum secara seimbang menuju terbentuknya ulama yang intelek.

Kemampuan orang yang berpendidikan, beradab untuk memberi manfaat bagi kemanusiaan, serta kapasitas mereka untuk berkomunikasi dengan orang lain, adalah tujuan pembelajaran yang menciptakan pemahaman dan berbagi nilai-nilai ini dalam komunikasi universal. Tujuannya adalah untuk terlibat dalam upaya kolaboratif untuk menyelesaikannya masalah global dan menciptakan masyarakat beradab yang berbagi pengetahuan untuk kepentingan semua.

\section{Kesimpulan}

Jelaslah bahwa kewajiban pendidikan dalam mendidik moral, intelektual dan budaya di tradisi Muslim tidak jauh dari tujuan dan konsep serupa yang terkait dengan tradisi Barat pada aspek pendidikan. Beberapa sarjana telah menghasilkan studi akademis yang luas tentang sejarah yang diketahui koneksi antara tradisi ini, dan dapat melacak jalur transmisi yang jelas antara nilai-nilai dan metode pendidikan yang mengalir ke peradaban Muslim dari tradisi klasik. Dua budaya pemahaman telah diambil dari warisan intelektual yang sama yakni tradisi standar moral dan etika, warisan Yunani. Esai ini mengingatkan bahwa istilah, Islam, dalam wacana publik sering terpisah dan terasing seperti pendidikan dari asosiasi budaya apa pun yang mungkin tertulis di media barat. Memunculkan pesantren sebagai lembaga pendidikan yang dapat diteliti oleh para sarjana barat sebagai bukti empiris pelaksanaan pendidikan islam yang akomodatif terhadap perdamaian global menjadi sangat penting. Diharapkan tingkat keakraban konseptual dan kelembagaan dapat dibangun untuk menjembatani ide-ide dari lembaga pendidikan saat ini. Sehingga kontribusi pendidikan sebagai jembatan pengetahuan yang memberi pencerahan dalam perdamaian dunia dapat diwujudkan segera.

\section{Referensi}


Afrianto, Dedy. "Pandemi: Dari Kesehatan, Ekonomi, Hingga Politik." Kompas, 22 Juli, 2020.

Akmansyah, Muhammad. "Al-Quran dan Al-Sunnah Sebagai Dasar Ideal Pendidikan Islam.” Ijtimaiyya: Jurnal Pengembangan Masyarakat Islam 8, no. 2 (2015): 127-42.

Alwi, B. Marjani. "PONDOK PESANTREN: Ciri Khas, Perkembangan, Dan Sistem Pendidikannya.” ," Lentera Pendidikan 16, no. 2 (2013): 205-19.

Arifin, Zainal. "Budaya Pesantren Dalam Membangun Karakter Santri." Al Qodiri : Jurnal Pendidikan, Sosial Dan Keagamaan 6, no. 1 (April 2014): 1-22

Badiusman, Badiusman. "Pembinaan Disiplin Beribadah Santri di Pondok Pesantran Iqra' Barung-Barung Balantai Kecamatan Koto XI Tarusan Kabupatan Pesisir Selatan.” Ruhama : Islamic Education Journal 1, no. 1 (Mei 2018): 13-23.

Cahyono, Heri dan Arief Rifkiawan Hamzah. “Agama dan Tantangan Budaya Modern Perspektif Islam.” Fikri : Jurnal Kajian Agama, Sosial Dan Budaya 1, no 2 (2016): 421-48.

Dana, Muhammad Arya. "At-Tarbiyah Sebagai Konsep Pendidikan Dalam Islam.” INOVATIF: Jurnal Penelitian Pendidikan, Agama Dan Kebudayaan 6, no. 1 (Februari 2020): 88-104.

Djamal, Samhi Muawan. "Pelaksanaan Nilai-Nilai Ajaran Islam Dalam Kehidupan Masyarakat Di Desa Garuntungan Kecamatan Kindang Kabupaten Bulukumba.” Jurnal Adabiyah 17, no. 2 (2017): 161-79.

Habibi, Moh. Mizan. "Corak Pendidikan Islam Inklusif." El-Tarbawi 10, no. 1 (2017): 35-48.

Halil, Hermanto. "Inovasi Kurikulum Pesantren dalam Memproyeksikan Model Pendidikan Alternatif Masa Depan.” UUlumuna: Jurnal Studi Keislaman 1, no. 2 (2015): 146-68.

Huda, Mualimul. "Eksistensi Pesantren Dan Deradikalisasi Pendidikan Islam Di Indonesia (Menyemai Spirit Toleransi Dan Pendidikan Islam Multikultural).” FOKUS: Jurnal Kajian Keislaman Dan Kemasyarakatan 3, no. 1 (2018): 87-102.

Huda, Sokhi. "Islam Dan Politik: Doktrin, Realitas, Dan Akses Sosiologisnya."

Makalah Dipresentasikan pada Seminar Kelas Mata Kuliah Sosiologi Agama pada Program Pascasarjana Institut Agama Islam Negeri Sunan Ampel Surabaya, Juni 1999

Husin. "Pendidikan Agama Islam di Amerika Serikat (Lembaga Pendidikan Islam).” Al-Madrasah: Jurnal Pendidikan Madrasah Ibtidaiyah 2, no. 2 
(Januari-Juni 2018): 48-58.

Ibda, Hamidulloh. "Relasi Nilai Nasionalisme dan Konsep Hubbul Wathan Minal Iman dalam Pendidikan Islam.” International Journal Ihya' 'Ulum Al-Din 19, no. 2 (2017): 245-270.

Imron, Ali, Hamzah, dan Agus Yudiawan. "Integrasi Kurikulum Pondok Pesantren Dalam Peningkatan Pemahaman Agama Islam Di SMP IT Nurul Yaqin Kabupaten Sorong.” Al-Fikr: Jurnal Pendidikan Islam 3, no. 1 (2017): $1-9$.

Jasminto. "Sumbangsih Pesantren dalam Historiografi Nusantara Sebuah Kajian Pendidikan Islam." Jurnal Islam Nusantara 1, no. 1 (2017): 61-71.

—. "Urgensi Teori Andragogi Dalam Memperkuat Visi Moderat Islam Di Indonesia." Proceedings of Annual Conference for Muslim Scholars (AnCoMS), Book Series 2 (2018): 643-51.

Kahfi, Muhammad. "Peranan Muhammadiyah Sebagai Gerakan Islam Berkemajuan di Era Modern.” Al-Risalah 11, no. 2 (2020): 110-28.

Kholik, Abdul. "Pendidikan Islam Dan Fenomena Radikalisme Agama." Jurnal Kependidikan 5, no. (2017): 10-19.

Khotimah, Husnul. "Internalisasi Moderasi Beragama Dalam Kurikulum

Pesantren," Rabbani: Jurnal Pendidikan Agama Islam 1, no. 1 (Maret 2020): $62-68$.

Killian, Nursinita. "Peran Teknologi Informasi Dalam Komunikasi Antar Budaya Dan Agama." Jurnal Dakwah Tabligh 15, no. 2 (2014): 159-76.

Kim, Young Y. Intercultural Transformation." In Becoming Intercultural: An Integrative

Theory of Communication and Cross-Cultural Adaptation. Thousand Oaks, Californiaa: SAGE Publications, Inc., 2001.

Machsun, Toha. "Pendidikan Adab, Kunci Sukses Pendidikan.” EL-BANAT: Jurnal Pemikiran Dan Pendidikan Islam 6, no. 2 (Desember 2016): 102-13.

Mappasiara. "Pendidikan Islam (Pengertian, Ruang Lingkup Dan Epistemologinya).” Inspiratif Pendidikan 7, no. 1 (2018): 47-60.

Marpaung, Enrico, Luthfi Adrian, Nisa Asror, dan Sherina Putri. "Pandemi

COVID-19: Dampak Sosial-Ekonomi, Tantangan, Dan Potensi Solusi (Sudut Pandang Sosiologis)." (Makalah Dipresentasikan sebagai Tugas Mata Kuliah Demografi Sosial, Jakarta, Mei 2020).

Maryamah. "Pendidikan Islam Masa Dinasti Abbasiyah." Tadrib: Jurnal Pendidikan Agama Islam 1, no. (2015): 47-65.

Matrapi. "Tipologi Pemikiran Pendidikan Islam (Membangun Sebuah Paradigma

Pendidikan Yang Mampu Menjadi Wahana Bagi Pembinaan Dan 
Pengembangan Peserta Didik).” Islamuna: Jurnal Studi Islam 5, no. 1 (2018): $1-15$.

Moordiningsih. "Islamophobia Dan Strategi Mengatasinya." Buletin Psikologi 12, no. 4 (Desember 2004): 73-84.

Mubarok, Ahmad Agis, dan Diaz Gandara Rustam. "Islam Nusantara: Moderasi Islam di Indonesia." Journal of Islamic Studies and Humanities 3, no. 2 (2018): $153-68$

Muhakamurrohman, Ahmad. "Pesantren: Santri, Kiai, dan Tradisi." Ibda` : Jurnal Kajian Islam Dan Budaya 12, no. 2 (Juli 2014): 109-18.

Mujab, M. "Studi Konstruksi Historis Pendidikan Islam Era Klasik Hingga Modern.” El-Hikmah 9, no. 1 (2012): 40-56.

Mukhibat. "Meneguhkan Kembali Budaya Pesantren dalam Merajut Lokalitas, Nasionalitas, dan Globalitas." KARSA: Journal of Social and Islamic Culture 23, no. 2 (2015): 177-92.

Mukodi. "Pesantren dan upaya deradikalisasi agama." Walisongo 23, no. 1 (2015): 89-112.

Mursalin, Ayub dan Ibnu Katsir. "Pola Pendidikan Keagamaan Pesantren Dan Radikalisme: Studi Kasus Pesantren-Pesantren Di Provinsi Jambi." Kontekstualita: Jurnal Penelitian Sosial Keagamaan 25, no 2 (2010).

Mursyid, Ali. "Pendidikan Nilai-Nilai Kebangsaan Di Pesantren: Riset Di Pesantren Ashidiqiyah Jakarta Barat.” MISYKAT: Jurnal Ilmu-Ilmu Al-Quran, Hadist, Syari'ah Dan Tarbiyah 3, no. 2 (2018): 125-56

Muttaqin. "Pemikiran dan Manajemen Pendidikan NU dan Muhammadiyah." Nur El-Islam: Jurnal Pendidikan Dan Sosial Keagamaan 4, no. 1 (April 2017): $1-39$.

Nadia, Zunly Nadia. "Perilaku Keagamaan Komunitas Muslim (Pemahaman Hadis

Dalam NU Dan Salafi Wahabi Di Indonesia).” Jurnal Living Hadis 2, no 2 (2017): 141-77.

Napitupulu, Dedi dan Syawal Fahmi. "Pendidikan Islam Muslim Minoritas (Kasus

Di Eropa Barat).” Belajea; Jurnal Pendidikan Islam 5, no. 1 (May 2020): 37 50 .

Nurkholipah, Nurkholipah. "Pengaruh Penyuluhan Agama Islam Terhadap Kesadaran Beragama Kepada Masyarakat.” Irsyad: Jurnal Bimbingan, Penyuluhan, Konseling, Dan Psikoterapi Islam 5, no. 3 (2017): 287-310.

Nurmadiah. "Kurikulum Pendidikan Agama Islam.” Al-Afkar: Jurnal Keislaman 8 Peradaban 2, no. 2 (2014) : 41-54.

Purnamasari, Nia Indah. "Konstruksi Sistem Pendidikan Pesantren Tradisional 
Di Era Global; Paradoks Dan Relevansi.” EL-BANAT: Jurnal Pemikiran Dan Pendidikan Islam 6, no. 2 (Desember 2016): 73-91.

Rizal, Muhammad, Muhammad Iqbal, dan Najmuddin. "Model Pendidikan Akhlaq Santri Di Pesantren Dalam Meningkatkan Akhlaq Siswa Di Kabupaten Bireuen.” Nadwa 12, no. 1 (2018): 89-116.

Rofik. "Nilai Pembelajaran Sejarah Kebudayaan Islam Dalam Kurikulum Madrasah.” Jurnal Pendidikan Agama Islam 12, no. 1 (2015): 15-30.

Rofiq, Nur. "Telaah Konseptual Implementasi Slogan Hubb Al-Wathan min AlIman KH. Hasyim Asy'ari dalam Pendidikan Karakter Cinta Tanah Air.” Jurnal Keluarga Sehat Sejahtera 16, no. 32 (2018): 44-52.

Rohmadi, Syamsul Huda. "Pendidikan Islam Inklusif Pesantren ( Kajian Historis Sosiologis Di Indonesia ).” FIKROTUNA 5, no. 1 (Juli 2017): 1-17.

Rozak, Abd. "Al-Quran, Hadis, dan Ijtihad Sebagai Sumber Pendidikan Islam." Fikrah: Journal of Islamic Education 2, no. 2 (December 2018): 85-101.

Said, Colle. "Paradigma Pendidikan Dalam Perspektif Surah Al-Alaq Ayat 1-5." Hunafa: Jurnal Studia Islamika 13, no. 1 (2016): 91-117.

Sakti, Muhammad Bimo, Irawan Suntoro, dan Yunisca Nurmalisa. "Peranan Pesantren Dalam Menumbuhkan Wawasan Kebangsaan Kepada Santri.” Jurnal Kultur Demokrasi 5, no. 12 (2018): 10-20.

Saputra, Inggar. "Resolusi Jihad: Nasionalisme Kaum Santri Menuju Indonesia Merdeka.” Jurnal Islam Nusantara 3, no. 1 (2019): 205-37.

Sindi, Hanan Qisthina, Reni Windiani dan Sheiffi Puspapertiwi. "Analisis Perilaku Kejahatan Terorisme Osama Bin Laden.” Journal of International Relations 2, no. 4 (2016): 93-98.

Siregar, Ferry Muhammad, dan Surahman Amin. "Ilmu dan Orang Berilmu dalam Al-qur'an: Makna Etimologis, Klasifikasi, dan Tafsirnya.” Empirisma: Jurnal Pemikiran dan Kebudayaan Islam 24, no. 1 (2015): 131-141.

Sodikin, R. Abuy. "Konsep Agama dan Islam.” Al-Qalam 20, no. 97 (April-June 2003): 1-20.

Syafe'i, Imam. "Pondok Pesantren: Lembaga Pendidikan Pembentukan Karakter." Al-Tadzkiyyah: Jurnal Pendidikan Islam 8, no. 1 (2017): 61-82.

Wage, dan A. Sulaeman. "Pemberdayaan Pendidikan Agama Islam Di Sekolah Dan Perguruan Tinggi Umum.” Islamadina: Jurnal Pemikiran Islam 17, no. 2 (2016): 31-40.

Wahyuddin. "Sumber-Sumber Pendidikan Islam (Penalaran, Pengalaman, Intuisi, Ilham Dan Wahyu)." Inspiratif Pendidikan 7, no. 1 (2018): 133-46.

Wasito. "Respon Barat Terhadap Islam Sebagai Sumber Peradaban." Jurnal 
Pemikiran Keislaman 24, no. 2 (2013): 48-58.

Widiani, Desti. "Konsep Pendidikan dalam Perspektif Al-Qur'an.” Murabby: Jurnal Pendidikan Islam 1, no. 2 (September 2018): 185-96.

Wirian, Oktrigana. "Kewajiban Belajar dalam Hadis Rasulullah SAW." Jurnal Sabilarrasyad 2, no. 2 (2017): 41-54. 